\title{
Examen de los niveles de estrés de las mujeres según las etapas de cambio de comportamiento del ejercicio y el estado de autoestima
}

\section{Examination of stress levels of women according to exercise behavior change stages and self-feeling status}

\author{
Cisem Unlu ${ }^{1}$, Aykut Aksu ${ }^{2 a}$, Osman Imamoglu ${ }^{3}$, Murat Erdogdu ${ }^{4}$, \\ Kursat Karacabey ${ }^{5}$

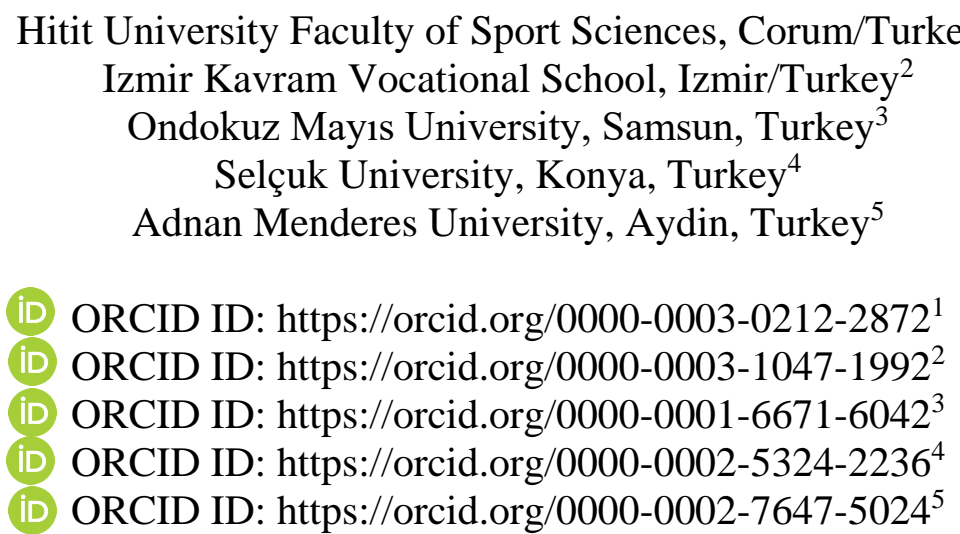

Recibido: 2 de setiembre de 2021

Aceptado: 28 de diciembre de 2021

\section{Resumen}

El objetivo de este estudio es examinar los niveles de estrés de las mujeres sedentarias según las etapas del cambio de comportamiento del ejercicio y el estado de sentirse ellas mismas. Se incluyeron en el estudio cuatrocientas sesenta mujeres sedentarias que completaron las encuestas en Samsun. Se aplicó una encuesta sobre el nivel de estrés percibido y el cambio en el comportamiento del ejercicio. El estado de salud de las mujeres sedentarias se encontró con un 20,12\% muy bueno, un 43,13\% bueno, un 24,08\% promedio y un $12,57 \%$ malo. Se encontró que los puntos de estrés de las mujeres sedentarias eran 29,92 puntos para las que tenían buena salud y 36,72 puntos para las que tenían mala salud. Se encontró también que los puntajes de estrés de los participantes en la actividad física regular durante los últimos 6 meses y 3 años eran más bajos que los que no participaron $(\mathrm{p}<0,05)$. Mientras que los niveles de estrés percibidos por las mujeres sedentarias según las etapas de cambio de comportamiento del ejercicio eran altos antes de la tendencia, fueron bajos durante la etapa de mantenimiento del ejercicio. Para reducir el nivel de estrés percibido de las mujeres sedentarias, se recomienda que estén en la fase de mantenimiento de sus conductas de ejercicio.

Palabras clave: Mujer sedentaria, estrés, comportamiento de ejercicio, estilo de vida. 


\begin{abstract}
The aim of this study is to examine the stress levels of sedentary women according to the stages of exercise behavior change and the state of feeling themselves. Four hundred and sixty sedentary woman who completed the surveys in Samsun were included in the study. Perceived stress level and change in exercise behavior survey were applied. Health status of sedentary woman were founded with $20.12 \%$ very good, $43.13 \%$ good, $24.08 \%$ average, and $12.57 \%$ bad. Sedentary woman stress points were found to be 29.92 points for those with good health and 36.72 points for those with bad ones. Stress scores of participants in regular physical action for the latest 6 months and 3 years were found to be lower than those who did not participate $(\mathrm{p}<0.05)$. While the stress levels perceived by sedentary women according to the exercise behavior change stages were high before the tendency, they were low during the exercise maintenance stage. In order to reduce the perceived stress level of sedentary women, it is recommended that they be in the maintenance phase of their exercise behaviors.
\end{abstract}

Keywords: Sedentary woman, stress, exercise behaviour, lifestyle.

\title{
Introduction
}

Especially after the second half of the 20th century, postmodern approaches, which started to be effective in many areas of life, also caused significant changes in perceptions of health, illness and treatment methods (Gezen \& Becerikli, 2019). In the postmodern period, youth and beauty are not only an ideal but also the body is expressed as an accessible, changeable, and reliable goal (Özbolat, 2011). Body perception confronts us as postmodernism (Köse et al., 2016). Studies in the literature suggest that individuals participating in physical activity at an insufficient level are shier than individuals participating in regular physical activity (Page \& Zarco, 2001). It is stated that being physically active has a positive effect on overcoming psychological and social problems (Bandura, 1993). Physical inactivity is one of the most important causes of anxiety among woman (Page \& Zarco, 2001). People who are not physically active tend to avoid more health benefits than physical fitness (Korepanova \& Panachev, 2014). There is a great deal reasons for individuals to participate in physical activity. These are being healthy, weight loss, good looking, social interaction, popular, etc. (Alemdağ et al., 2016; Allender at al., 2006). More stationary lifestyle on woman is available in Turkey (Aktener et al., 2006; Yildırım et al., 2012).

Participation in physical activity has decreased among adult people. In this context, it is stated that the prevalence of a series of health problems has increased, especially in industrialized countries (Abraham \& Graham-Rowe, 2009; Dugdill et al., 2008). It is put forward that only $25 \%$ of the society in Turkey have sufficient physical 
activity level, $37 \%$ have low activity level, and 38\% lead a sedentary life (http://aktifyasam.org.tr/projeler,2017). These percentage is quite low when it compares European countries (Aksoy \& Ziyagil, 2017). Various theories and models have been used to healthy behaviors (Rejeski \& Fanning, 2019). People's behaviors toward exercise are classified into 5 different phases of change. Pre contemplation phase: In this phase has people with no intention to exercise. Contemplation phase: This phase has people with the intention to exercise but not in action. In Preparation phase has people who intend to take action in the next months. Action phase has people who participate in regular exercise for a period of less than 6 months. In Maintenance phase's individual are finding who participate in regular exercise for more than six months (Marcus \& Forsyth, 2008).

For the other hand, stress is a phrase that is used to describe the body's psychological and/or physiological response to conditions that require behavioral readjustment (Nakao, 2010). Stress is considered as a critical factor in the onset, course and aggravation of many diseases. Many cardiovascular diseases, many immune-related disorders, trauma, depression, and it has been related to higher overall mortality for humans (Bachen et al.,2007; Wiegner et al.,2015; Cohen et al.,2007; Nielsen et al.,2008). Overall, perceived stress is linked to reduced life satisfaction (Golden et al., 2005). Persons perceives this situation as nervous when he or she estimates that there was a disagreement between the demands of the situation and the actual psychosocial resources and competences. There be present found different potential areas for the effect of psychological distress on mental and physical health for human. These physiological responses may guidance to disturbances of physical and mental functioning for human over the longtime.

In addition, stress and its consequences on health for human has been a major research topic. In according resultant, there are finding a positive intercourse between sensed stresses and frequent of serious or unserious illness. Also, conducted studies determined that there was an association between health behaviors for human and perceived stress (Pascoe \& Richman, 2009). Many studies have shown an inconsistent of the effects of external stressors on health; therefore, recent studies have emphasized stress reaction, principally perceived stress (DeLongis et al., 1988). In order to exercise, woman who are pre-contemplation and at the stage of contemplation in behavior change steps must first be enter into preparation. Woman who are in the taking-action phase need to be motivated to act as soon as possible. It is thought that it is necessary for woman who are in the Maintenance phase in the movement to continue this behavior for their health. 
Also, it is thought that the stress level will change in inactive woman according to the stages of behavior change. For this cause, stress levels of inactive woman were examined according to the stages of exercise behavior change.

Therefore, one of the goals of this article is to determine the stress level according to the stage they are at in terms of exercise behavior of woman in Turkey. It was also tried to determine whether those who were in the phases of Action and Maintenance in the behavior change stages had a lower stress level than woman who were in the Precontemplation, Contemplation and Preparation stages.

\section{Methodology}

\section{Participants}

The research population represents the women who do not actively do sports in Turkey. The research sample is woman living in Samsun. A statistical process was applied to 554 woman who filled the questionnaires correctly and were not active athletes. This study is limited to sedentary woman between the ages of 22-40. Woman who were active athletes were not included in the study. The measurements to be included in the study were sedentary woman, no visual or hearing impairment, and no permanent disease. The following questionnaires and scales were used for data collection. In the personal information survey, the age, height and body weight of the woman were also asked. It is accepted that woman who do not do sports responded to the scales of their own free will, accurately and in a way to reflect themselves fully. Incomplete questionnaires were not included in the study. Data were collected in March, April and May 2018.

\section{Perceived stress scale}

In Turkey, this scale was validity and reliability studies were done by Erci (2006). Then were adapted to Turkish's community again (Bilge et al., 2009). This scale has comprised of 10 items and items are scored between1-5 points. These are never (1), almost never (2), sometime (3), fairly often (4), very often (5). The scale is easy understandable. The 4 items are scored as positive (Items: 4, 5, 7, 8). The 6 items for scale are scored as negative (Items: 1, 2, 3, 6, 9, 10). In total, is can to get a total score from 0 to 50. The main purpose of the scale is to measurement level of stress for humans. If the total score is low, the stress level is low. The higher the scale score, the higher the stress level (Eskin et al., 2013). In the present study, perceived Stress Scale had Cronbach's alpha of $\alpha=0.75$. 


\section{Physical Activity Stages of Change Questionnaire (PASCQ)}

The PASCQ evaluates man and woman exercise stages on their physical activity behaviors. The criterion validity of the Turkish version by Cengiz et al. (2010) made. Questions has measured with yes/no. The survey uses a scoring algorithm to classify individuals into 5 different phages of change. According Marcus \& Lewis (2003), these is namely Pre-Contemplation, Contemplation, Preparation, Action, and Maintenance. In pre-contemplation phase, is individuals do not changed their high-risk behavior in the foreseeable future (6 months' time). In Contemplation phase, people seriously intended to change their behavior in the next six months. In preparation, individuals intend to take action in the near future and usually in less than 6 months' time. In action phase, individuals have made overt behavior changes within the past 6 months' time. In maintenance phase, individuals have changed their behavior for more than 6 months' time (Nakamura et al., 2013). It was answered either "yes" or "no" based on their participation in physical activity for each question. Using the following scoring patterns, the behavioral tendency for 5 different exercises is made (Çeker et al., 2013). Behavior changed categories in the form of scoring: for questions: Yes (1) or No (0).

Pre-contemplation stage: If the question 1 and question 2 is no

Contemplation stage: If the question 1 yes and question 2 is no

Preparation stage: If the question 1 yes and question 3 is no

Decision/action stage: If the question 1 yes question 3 yes, and question 4 is no

Maintenance stage: If the question 1, 3 and question 4 is yes (Marcus and Lewis, 2003). The scale validity applied in this study is 0.83 .

\section{Statistical analysis}

The data were analyzed using the Statistical Package for Social Sciences Statistics (Version 23.0 for Windows; IBM). According to Shapiro Wilk's test, the data contained a normal distribution. Independent t-test was used for comparisons of binary variables, and ANOVA and LSD tests were used for multivariate difference. 


\section{Results}

\section{Table 1}

Anthropometric Characteristics of Sedentary Woman

\begin{tabular}{lll}
\hline Parameter & Mean & Standard deviation \\
\hline Age (Years) & 32.40 & $\mathbf{6 . 5 3}$ \\
Body Height $(\mathbf{c m})$ & 164.16 & $\mathbf{5 . 2 2}$ \\
Body weight $(\mathbf{k g})$ & 61.12 & $\mathbf{9 . 3 6}$ \\
BMI $\left(\mathbf{k g} / \mathbf{m}^{2}\right)$ & 22.17 & $\mathbf{3 . 2 7}$ \\
\hline
\end{tabular}

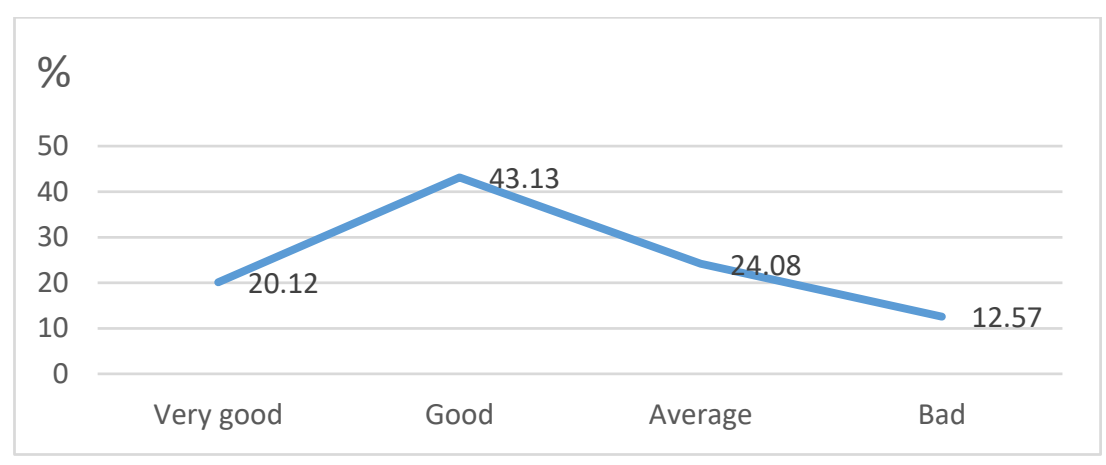

Graphic 1. Health status of sedentary woman display \% distribution

Table 2

Stress Point of Sedentary Woman according to General Health Status

\begin{tabular}{lllll}
\hline & N & Mean & $\begin{array}{l}\text { Standard } \\
\text { deviation }\end{array}$ & F/LSD \\
\hline Very good (1) & 110 & 29.92 & 4.52 & $\mathbf{3 . 1 8}^{*}$ \\
& & & & $\mathbf{1 , 2 < 4}$ \\
Good (2) & 216 & 30.35 & 5.66 & \\
Average (3) & 145 & 31.56 & 5.14 & \\
Bad (4) & 83 & 36.72 & 6.23 & \\
\hline Total & $\mathbf{5 5 4}$ & $\mathbf{3 0 . 5 5}$ & $\mathbf{5 . 3 9}$ & \\
\hline p $<0.05$ & & & &
\end{tabular}

According to Table 2, The stress score of sedentary women increased to 29.92 for those who stated their health status as very good, and to 36.72 for those who stated their health status as poor. The change in stress scores according to the perceived health status is statistically different ( $\mathrm{p}<0.05)$. 


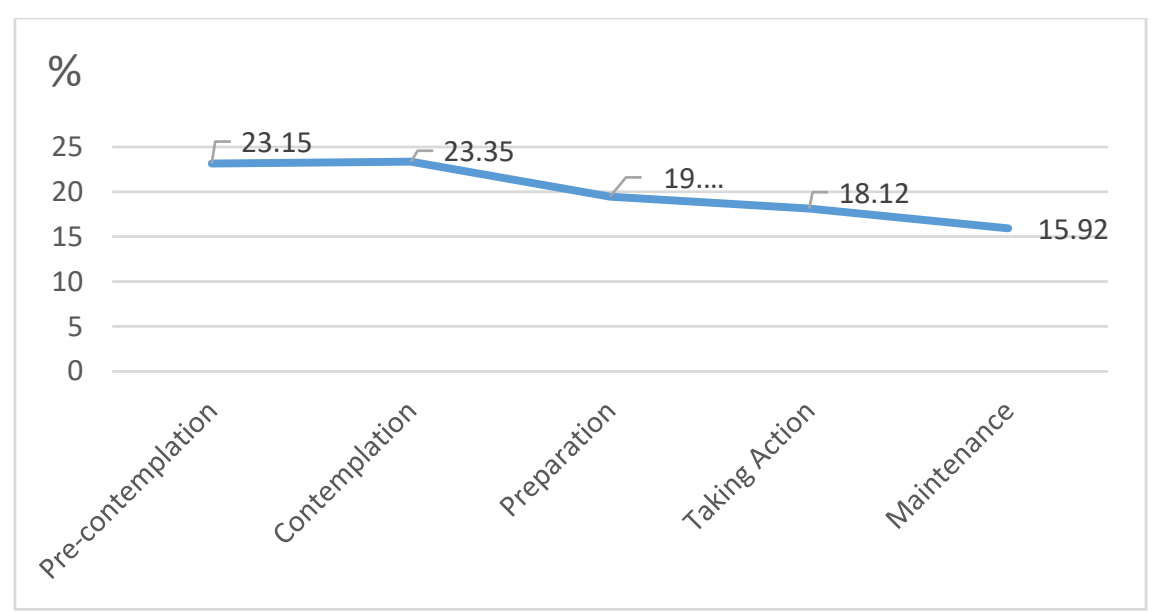

Graphic 2. Percentage distribution of sedentary woman according to Behavior change stages as woman physical activity increases, their stress scores decrease

Table 3

Distribution of Stress Points According to Woman Behavioral Change Stages

\begin{tabular}{lccll}
\hline Phase & N & Mean & Standard deviation & F/LSD \\
\hline Pre-contemplation (1) & 133 & 32,48 & 5.16 & $\mathbf{3 . 8 8}$ \\
Contemplation (2) & 124 & 31,80 & 5.43 & $\mathbf{1 , 2 > 4 , 5}$ \\
Preparation (3) & 113 & 30,62 & 5.64 & \\
Taking Action (4) & 98 & 29,27 & 5.32 & \\
Maintenance (5) & 86 & 28,59 & 6.33 & \\
$\quad$ Total & $\mathbf{5 5 4}$ & $\mathbf{3 0 , 5 5}$ & $\mathbf{5 . 6 5}$ & \\
*p $<0,05$ & & & &
\end{tabular}

According to Table 3, Sedentary woman have the highest stress level in the behavioral change stages in the pre- contemplation stage (32.48 points). The lowest stress level is woman who are in the Maintenance phase (28.59 points). The change in the stress level according to the behavior change steps was found to be statistically significant ( $p$ $<0.05)$.

Table 4

Stress Points of Participants in Regular Physical Activity at the last 6 Months and 3 Years

\begin{tabular}{lccccc}
\hline & Regular activity & $\mathbf{n}$ & mean & Standard deviation & t-test \\
\hline Stress point & Yes & 141 & 28.45 & 6.13 & $-2,63^{*}$ \\
(6 month) & No & 413 & 31.00 & 5.21 & \\
Stress point & Yes & 118 & 27.44 & 6.03 & $-3,58^{* *}$ \\
$(3$ Year) & No & 436 & 30.81 & 5.45 & \\
$* \mathrm{p}<0,05 \quad * \mathrm{p}<0,001$ & & & & &
\end{tabular}


While the stress score of those who participated in regular physical activity in the last 6 months was 28.45, the score of those who did not participate was found to be 31.00. While she stresses score of those who participated in regular physical activity in the last 3 years was 27.44, while the score of those who did not participate was 30.81 . The change in the stress level according to the behavior change steps was found to be statistically significant $(\mathrm{p}<0.05)$.

\section{Discussion}

Sedentary woman were included in this study. Attention was paid to the fact that the sedentary woman included in the study did not have visual or hearing impairment, did not have a permanent disease, and were not active athletes. In this study, the average age of sedentary woman were 32.40 years, Body height $164.16 \mathrm{~cm}$, Body weight $61.12 \mathrm{~kg}$, and BMI (Body Mass Index) $22.17 \mathrm{~kg} / \mathrm{m}^{2}$ (Table 1). In this study, were founded their health status of sedentary woman $20.12 \%$ very good, $43.13 \%$ good, $24.08 \%$ average, and 12.57\% bad (Graphic 1). The Perceived Stress Scale is a well-established self-report measure based on the psychological conceptualization of stress. The scale defines the degree to which situations in one's life are appraised as stressful (Cohen et al., 1983). Considering the highest score that can be obtained from Perceived Stress Scale was 50 and upwards scores indicated elevated levels of stress perception. In this study that mean Perceived Stress Scale scores of the sedentary woman was middle (29.95). This score suggests that sedentary woman generally do perceive themselves as lower stressful. It is known that perception of stress can be affected many factors. These can personal and environmental (Bilge et al., 2009).

Çetin (2018) in a study, found sedentary woman stress points 29.33 points for those with good health and 36.00 points for those with bad ones. In this study, sedentary woman stress points were found to be 29.92 points for those with very good health and 36.72 points for those with bad ones (Table 2). In a study Çetin and İmamoğlu (2021), they found that sedentary women with very good and good health had lower stress scores than those with poor health. In this study, sedentary woman whose health status is very good and good have lower stress scores. Those with poor health status had a high stress score. This difference was statistically significant $(\mathrm{p}<0.05)$. Sedentary woman should be having a good health condition to reduce stress situations.

Future studies on Woman Physical activity behaviors should be structured using the stages of change levels. Fine arts education can contribute to the positive reflections 
of the body image (İmamoğlu \& Demirtaş, 2017). In the study, titled Factors affecting the likelihood to engage in adequate physical activity to promote health, these variables include age, education level and perceived benefits of physical activity, lifestyle, motivation, and opportunities to participate in physical activity (Mullineaux et al., 2001). (Marcus \& Forsyth, 2008). In this study, Physical Activity Stages of Change were differences: Pre-contemplation (23.15\%), Contemplation (23.35\%), Preparation (19.46\%), Taking Action (18.12\%) and Maintenance (15.92\%), (Graphic 2). Çetin (2018) in a study, found according Behavioral Change Stages in phase of Pre-contemplation 31.84 and in phase of Maintenance of 28.03 stress points for sedentary woman. In this study, when total stress scores were analyzed in terms of the stages of behavior change, the highest average was found in those within the pre-contemplative stage with 32.48 , while the lowest average was found in those within the maintenance state with 28.59 (Table 3).

In another study Çetin and İmamoğlu (2021), they stress scores of the Precontemplation and Contemplation were significantly higher than those of the in phase of Action and Maintenance stages. In this study, as the stages of contemplation, preparation, action, and maintenance progress, the scores decrease compared to those in the precontemplation stage. The stress scores of the Pre-contemplation and Contemplation were significantly higher than those of the in phase of Action and Maintenance stages $(p<0.05)$. In that case, the sporting activity decreases the stress score. Physical activity or exercise has numerous health benefits among persons. Specifically, it reduces the risk of obesity and the development of chronic diseases, such as diabetes (World Health Organization, 2021). Exercise or physical activity reduced cardiovascular disease, and all-cause mortality (Tremblay et al., 2011). In the study, physical activity and exercise strengthen bones and muscles, improve mental health and mood, reduce depression and anxiety, and promote sociability (Hallal et al., 2006).

Physical activity or exercise is psychological well-being, and improves academic performance (Rasmussen \& Laumann, 2013). Yildırım et al., (2012) in a study in the Turkish context, woman who live in low socio-economic environments neighborhoods tended to have a higher risk of physical inactivity. Karadağ (2008) in a study reported, that young people having sports showed low stress scores. In this study, stress scores of participants in regular physical activity for the last 6 months and 3 years were found to be lower than those who did not participate $(\mathrm{p}<0.05)$. Health programs for woman should 
be developed and administered upon taking the level of physical activity, exercise stages into consideration.

For the other hand, sports activities can reduce perceived stress. In a study, found Pilates and aerobic exercises contributed positively to the body image in obese woman (Çetinkaya \& İmamoğlu, 2018). In this study, the stress score of women who participated in regular activities for 3 years was 27.44, while the stress score of women who participated in regular activities for 6 months was 28.45 (Table 4). It can be said that the stress level of women who do regular activity/exercise decreases as the duration of exercise (in months and years) increases.

Also, it was observed that the expectation that the stress levels of sedentary woman who are physically active will be lower than those who are not physically active were realized. It is also confirmed that those who perceive their health status as good will have lower stress levels than those who perceive their health status as bad. In addition, the hypothesis that sedentary woman will decrease their stress levels as the duration of being physically active is accepted.

\section{Conclusion}

As a result; According to the research, stress levels of sedentary women in Turkey differ according to the stage they are in in terms of exercise behaviors. It has also been found that those who are in the Taking Action and Maintenance phase in behavior change stages have lower stress levels than woman who are in the Pre-contemplation, Contemplation and Preparation stages. Stress scores of sedentary woman vary according to their general health status. It has been found that those who perceive their health status as poor are more stressful.

Also, it has been determined that the stress levels of sedentary women who do regular activity/exercise decrease as the duration of physical activity increases (in months and years). It is recommended that sedentary women increase the percentage of continuity in exercise behaviors in order to reduce their perceived stress level. Stress level according to exercise behavior change stages should be investigated in a large number of sedentary woman in different regions in Turkey and they should be trained on exercise planning. 


\section{References}

Abraham, C., \& Graham-Rowe, E. (2009). Are worksite interventions effective in increasing physical activity? A systematic review and meta-analysis. Health Psychology Review, 3 (1), 108-144. https://doi.org/10.1080/17437190903151096

Aksoy, Y., \& Ziyagil, M. A. (2017). Effects of education and socioeconomic status on regular physical activity levels in males and females. New Trends and Issues Proceedings on Humanities and Social Sciences, 4 (5), 59-65. https://doi.org/10.18844/prosoc.v4i5.2676

Aktener, A. Y., Dülger, H. İ., Erkayhan, G. E., Görmeli, G., Kafadar, F. S., Yıldız, M., \& Soyer, A. (2006). Obesity prevalence in reproductive age and postmenopausal Female aged between 20-64 years in a semi-urban Area. Balkan Medical Journal, 2006 (3), 119-126. https://dergipark.org.tr/en/pub/bmj/issue/3752/49867

Alemdag, C., Alemdag, S., \& Ozkara, A. B. (2016). Physical activity as a determinant of subjective happiness. Baltic Journal of Sport and Health Sciences, 4 (103), 2-10. https://doi.org/10.33607/bjshs.v4i103.66

Allender, S., Cowburn, G., \& Foster, C. (2006). Understanding participation in sport and physical activity among children and adults: a review of qualitative studies. Health education research, $21 \quad$ (6), https://doi.org/10.1093/her/cyl063

Bachen, E. A., Cohen, S., \& Marsland, A. L. (2007). Psychoneuroimmunology. In: Baum, A., Newman, S., Weinman, J., West, R., \& McManus, C. (Eds.). Cambridge Handbook of Psychology, Health and Medicine. Cambridge, UK: Cambridge University Press, p. 167-72. http://assets.cambridge.org/97805218/79972/frontmatter/9780521879972_front matter.pdf

Bandura, A. (1993). Perceived self-efficacy in cognitive development and functioning. Educational psychologist, 28 (2), 117-148.

https://doi.org/10.1207/s15326985ep2802_3

Bilge, A., Öğce, F., Genç, R. E., \& Oran, N. T. (2009). Psychometric properties of a Turkish version of the perceived stress scale. Ege Universty Nursing College Sciences, 25 (2): 61-72.

Cengiz, C., Așç1, F. H., \& İnce, M. L. (2010). "Exercise stages of change questionnaire": its reliability and validity. Türkiye Klinikleri Spor Bilimleri, 2 (1), 32-37. https://www.turkiyeklinikleri.com/article/tr-egzersiz-davranisi-degisimbasamaklari-anketi-gecerlik-ve-guvenirlik-calismasi-57471.html

Chen, Y. H., \& Lin, H. C. (2011). Risk of cancer subsequent to severe depression-a nationwide population-based study. Journal of affective disorders, 131 (1-3), 200206. https://doi.org/10.1016/j.jad.2010.12.006 
Cohen, S., Janicki-Deverts, D., \& Miller, G. E. (2007). Psychological stress and disease. Jama, 298 (14), 1685-1687. doi:10.1001/jama.298.14.1685

Cohen, S., Kamarck, T., \& Mermelstein, R. (1983). A global measure of perceived stress. Journal of health and social behavior, 24 (4),385-396.

Doi: 10.2307/2136404 https://www.jstor.org/stable/2136404

Çeker, A., Cekin, R., \& Ziyagil, M. A. (2013). Stages of exercise behaviour changes in male and females from different age groups. CBU Physical Education and Sports Sciences, 8 (1), 11-20.

Çetin S., \& İmamoğlu O. (2021). Investigation of stress levels according to the exercise behavior change stages of women, Progress in Nutrition, 23 (1),1-8.

Çetin, S. (2018). Investigation of Female's quality of life and stress levels according to exercise behaviorc hange stages. Hitit University Institute of Social Sciences Department of Physical Education and Sports PhD Thesis, Çorum.

Çetinkaya, G., \& İmamoğlu, G. (2018). Investigation of the effect of plates-aerobic exercises on body composition and body image in obesity female. The Journal of International Social Research, $11 \quad$ (59), 1451-1456. https://www.sosyalarastirmalar.com/archive/jisr-volume-11-issue-59-year2018.html

DeLongis, A., Folkman, S., \& Lazarus, R. S. (1988). The impact of daily stress on health and mood: psychological and social resources as mediators. Journal of personality and social psychology, 54 (3), 486. https://doi.org/10.1037/0022-3514.54.3.486

Dugdill, L., Brettle, A., Hulme, C., McCluskey, S., \& Long, A. F. (2008). Workplace physical activity interventions: a systematic review. International Journal of Workplace Health Management, 1 20-40. https://doi.org/10.1108/17538350810865578

Erci, B. (2006). Reliability and validity of the Turkish version of perceived stress scale. Journal of Anatolia Nursing and Health Sciences, 9 (1): 58-63. https://dergipark.org.tr/tr/download/article-file/29299

Eskin, M., Harlak, H., Demirkiran, F., \& Dereboy, C. (2013). The adaptation of the perceived stress scale into Turkish: a reliability and validity analysis. In New Symp $J, 51$, pp. 132-140).

Gezen, A. K., \& Becerikli, S. Y. (2019). Gelenekselin Yeniden Üretimi: Postmodern Zamanın Bütünsel Sağlık Yaklaşımı. Online Journal of the Faculty of Communication $\quad$ Sciences, 27 (3),1-16. https://dergipark.org.tr/tr/download/article-file/1146835.

Güleryüz, E., \& Aydın, O. (2006). Job control and control at the request of the relationship between burnout and physical health. Turkish Journal of Psychology, 21 (58): 5971. 
Golden-Kreutz, D. M., Thornton, L. M., Gregorio, W. D., Frierson, G. M., Jim, H. S., Carpenter, K. M., Shelby, R. A., \& Andersen, B. L. (2005). Traumatic stress, perceived global stress, and life events: prospectively predicting quality of life in breast cancer patients. Health Psychology, 24 (3), 288.

Hallal, P.C., Victora, C.G., Azevedo, M.R., \& Wells, J.C. (2006). Adolescent physical activity and health: A systematic review. Sports Medicine, 36 (12), 1019-1030. https://doi.org/10.1037/0278-6133.24.3.288

Hammen, C. (2006). Stress Generation in Depression: Reflection on Origins, Research and Future Directions. Journal of Clinical Psychology, 62, 1065-1082. http://dx.doi.org/10.1002/jclp.20293

İmamoğlu, G., \& Demirtaş, Ö. (2017). Investigation of students' views who receive art and religious training about body image. Uluslararası Kültürel ve Sosyal $\begin{array}{llll}\text { Araştırmalar } \quad \text { Dergisi } & \text { (UKSAD), } 3 & \text { (2), }\end{array}$ https://dergipark.org.tr/tr/pub/intjcss/issue/33182/369821

Kadzikowska-Wrzosek, R. (2012). Perceived stress, emotional ill-being and psychosomatic symptoms in high school students: the moderating effect of selfregulation competences. Archives of Psychiatry and Psychotherapy, 3, 25-33.

Karadağ, Ö. (2008). Evaluation of sociodemographic characteristics and physical activity level of adolescents living in orphanages in Ankara in terms of mental symptoms and quality of life. Ankara: Hacettepe University, Master Thesis.

Korepanova, Y. A., Panachev, V. D. (2014). Students' healthy life -style components study. Russ J Phys Educ Sport, No. 9 (2),32-8.

Köse, E., Bayköse, N., Bal- Turan, E., \& Yerlisu-Lapa, T. (2016). Düzenli egzersiz yapan bireylerde olumsuz değerlendirilme korkusunun vücut algılarını belirlemedeki rolü. Mediterranean Journal of Humanities, 6, (2), 351-360. DOI:10.13114/MJH.2016.303

Marcus, B. H., \& Forsyth, L. H. (2008). Motivating people to be physically active. Human Kinetics.

Marcus, B. H., \& Lewis, B. A. (2003). Physical activity and stages of change of motivational readiness for change model. President's Council on Physical Fitness and Sport Research Digest, 4 (1), 1-8.

Mullineaux, D. R., Barnes, C. A., \& Barnes, E. F. (2001). Factors affecting the likelihood to engage in adequate physical activity to promote health. Journal of sports sciences, 19 (4), 279-288. https://doi.org/10.1080/026404101750158376

Nakamura, P. M., Papini, C. B., Teixeira, I. P., Sebastião, E., Gobbi, S., Cordeira, K. L., $\&$ Kokubun, E. (2013). Concordance between Stages of Behavior Change Questionnaire and IPAQ. Motriz: Revista de Educação Física, 19 (4), 776-782.

Nakao, M. (2010). Work-related stress and psychosomatic medicine. Bio Psycho Social medicine, 4 (1), 4. 
Nielsen, N. R., Kristensen, T. S., Schnohr, P., \& Grønbæk, M. (2008). Perceived stress and cause-specific mortality among men and Female: results from a prospective cohort study. American journal of epidemiology, 168 (5), 481-491.

https://doi.org/10.1093/aje/kwn157

Özbolat, A. (2011). Rebuilding of the Body on The Basis of Consumption in Postmodernism, Electronic Journal of Social Sciences, 10 (38), 317-334.

Page, R. M., \& Zarco, E. P. (2001). Shyness, physical activity, and sports team participation among Philippine high school students. Child Study Journal, 31 (3), 193-205.

Pascoe E.,Richman L. (2009). Perceived Discrimination and Health: A Meta-Analytic Review, Psychological Bulletin, 135 (4):531-54.

Rasmussen, M., \& Laumann, K. (2013). The academic and psychological benefits of exercise in healthy children and adolescents. European Journal of Psychology of Education, 28 (3), 945-962.

Rejeski W.J.,Fanning J. (2019). Models and theories of health behavior and clinical interventions in aging: a contemporary, integrative approach, Clin Interv Aging, 14: 1007-1019.

Richardson, S., Shaffer, J. A., Falzon, L., Krupka, D., Davidson, K. W., \& Edmondson, D. (2012). Meta-analysis of perceived stress and its association with incident coronary disease. The American Journal of Cardiology, 110 (12), 1711-1716. https://doi.org/10.1016/j.amjcard.2012.08.004

Suzanne C. S. and Gregory E. M. (2004). Psychological Stress and the Human Immune System: A Meta-Analytic Study of 30 Years of Inquiry, Psychol Bull, 130 (4): 601-630.

Tremblay, M. S., Leblanc, A. G., Kho, M. E., Saunders, T. J., Larouche, R., Colley, R. C., Goldfield, G., \& Gorber, S. C. (2011). Systematic review of sedentary behaviour and health indicators in school-aged children and youth. International Journal of Behavioral Nutrition \& Physical Activity, 8 (98), 2-22.

World Health Organization (2021). Diabetes, https://www.who.int/news-room/factsheets/detail/diabetes.

Wiegner, L., Hange, D., Björkelund, C., \& Ahlborg, G. (2015). Prevalence of perceived stress and associations to symptoms of exhaustion, depression and anxiety in a working age population seeking primary care-an observational study. BMC family practice, 16 (1), 38. doi: 10.1186/s12875-015-0252-7.

Yildirim, G., Ince, M. L., \& Muftuler, M. (2012). Physical activity and perceptions of neighborhood walkability among Turkish Female in low and high socioeconomic environments: an exploratory study. Perceptual and Motor Skills, 115 (2), 